\title{
Qualitative and Quantitative Phase-Analysis of Undoped Titanium Dioxide and Chromium Doped Titanium Dioxide from Powder X-Ray Diffraction Data
}

\author{
Hari Sutrisno ${ }^{1, *}$, Ariswan $^{2}$, and Dyah Purwaningsih ${ }^{1}$ \\ ${ }^{1}$ Department of Chemistry Education, Faculty of Mathematics and Natural Sciences, Universitas Negeri Yogyakarta (UNY), \\ Jl. Colombo No.1, Yogyakarta 55281, Indonesia \\ ${ }^{2}$ Department of Physics Education, Faculty of Mathematics and Natural Sciences, Universitas Negeri Yogyakarta (UNY), \\ Jl. Colombo No.1, Yogyakarta 55281, Indonesia
}

Received October 11, 2017; Accepted February 2, 2018

\begin{abstract}
Undoped titanium dioxide $\left(\mathrm{TiO}_{2}\right)$ and a series of chromium(III) doped $\mathrm{TiO}_{2}\left(\mathrm{Cr}\right.$-doped TiOfig. $\left.1_{2}\right)$ with various $\%$ wt $\mathrm{Cr}$ atom were prepared by a reflux technique. The undoped $\mathrm{TiO}_{2}$ and $\mathrm{Cr}$-doped $\mathrm{TiO}_{2}$ of 1.1, 3.9, $4.4 \%$ wt $\mathrm{Cr}$ atom have been successfully analyzed both qualitative and quantitative analysis of powder X-ray diffraction (XRD) data. The qualitative analysis was carried out with the identification of phases in all samples by comparison with Crystallography Open Database (COD) and International Centre for Diffraction Data (ICDD), while the quantitative phase analysis was calculated by reference intensity ratio (RIR) and whole-pattern fitting (Rietveld analysis) methods. The undoped $\mathrm{TiO}_{2}$ consist of three phases: anatase, rutile, and brookite. In the $1.1 \%$ wt Cr-doped $\mathrm{TiO}_{2}$ are detected presenting two phases: anatase (major) and rutile (minor). In the $3.9 \%$ wt Cr-doped $\mathrm{TiO}_{2}$ and in the $4.4 \%$ wt Cr-doped $\mathrm{TiO}_{2}$ consist of anatase as major phase, while $\mathrm{CrO}_{2}$ and $\mathrm{TiO}_{2}-I I$ phases can be detected as minor phases. The undoped $\mathrm{TiO}_{2}$ was refined in the phase, crystal system and space group of anatase (tetragonal, $14_{1} /$ amd), rutile (tetragonal, $\mathbf{P} 4_{2} / \mathrm{mnm}$ ) and brookite (orthorhombic, Pbca), while the $1.1 \%$ wt Cr-doped $\mathrm{TiO}_{2}$ was refined based on anatase (tetragonal, $14_{1} / \mathrm{amd}$ ), rutile (tetragonal, $\mathbf{P} 4_{2} / \mathrm{mnm}$ ). Finally, in the $3.9 \% w t$ Cr-doped $\mathrm{TiO}_{2}$ and $4.4 \% w t \mathrm{Cr}$ doped $\mathrm{TiO}_{2}$, respectively were refined in the crystal system and space group of anatase (tetragonal, $14_{1} / \mathrm{amd}$ ).
\end{abstract}

Keywords: titanium dioxide; Rietveld analysis; X-ray powder diffraction

\section{ABSTRAK}

Titanium dioksida $\left(\mathrm{TiO}_{2}\right)$ dan $\mathrm{TiO}_{2}$ terdadah variasi \% berat $\mathrm{Cr}(\mathrm{III})$ berhasil dipreparasi dengan teknik refluks. Titanium dioksida dan $\mathrm{TiO}_{2}$ terdadah 1,1;3,9; dan 4,4\% berat atom $\mathrm{Cr}$ dianalisis secara kualitatif dan kuantitatif dari data difraksi sinar-X (XRD) serbuk. Analisis kualitatif dilakukan dengan cara mencocokkan data pola XRD sampel dengan data pola XRD standard dari Crystallography Open Database (COD) dan International Centre for Diffraction Data (ICDD). Analisis kuantitatif dihitung berdasarkan metode "reference intensity ratio" (RIR) and "whole-pattern fitting" (metode Rietveld). Sampel $\mathrm{TiO}_{2}$ berisi tiga fasa kristal: anatas, rutil, dan brookit, sedangan $\mathrm{TiO}_{2}$ terdadah $1,1 \%$ berat atom $\mathrm{Cr}$ mengandung dua fasa: anatas (utama) dan rutil (minor). Masing-masing, pada $\mathrm{TiO}_{2}$ terdadah $3,9 \%$ berat atom $\mathrm{Cr}$ dan $\mathrm{TiO}_{2}$ terdadah $4,4 \%$ berat atom $\mathrm{Cr}$ terkandung anatas sebagai fasa utama, sedangkan fasa $\mathrm{CrO}_{2}$ dan $\mathrm{TiO}_{2}-$ Il hadir dalam jumlah sangat sedikit. Penghalusan Rietveld pada $\mathrm{TiO}_{2}$ dilakukan dengan berdasarkan atas fasa, sistem kristal dan kelompok ruang: anatas (tetragonal, $1 \mathbf{4}_{1} / \mathrm{amd}$ ), rutil (tetragonal, $\mathbf{P} \mathbf{4}_{2} / \mathrm{mnm}$ ) dan brookit (ortorombik, Pbca), sedangkan pada $\mathrm{TiO}_{2}$ terdadah $1,1 \%$ berat atom $\mathrm{Cr}$ dilakukan penghalusan berdasar atas sistem kristal dan kelompok ruang: anatas (tetragonal, $1 \mathbf{4}_{1} / \mathrm{amd}$ ) and rutil (tetragonal, $\mathbf{P} \mathbf{4}_{2} / \mathrm{mnm}$ ). Akhirnya, penghalusan struktur pada $\mathrm{TiO}_{2}$ terdadah 3,9\% berat atom $\mathrm{Cr}$ dan pada $\mathrm{TiO}_{2}$ terdadah $4,4 \%$ berat atom $\mathrm{Cr}$ dilaksanakan berdasar atas sistem kristal dan kelompok ruang: anatas (tetragonal, 14/amd).

Kata Kunci: titanium dioksida; analisis Rietveld; difraksi sinar-X serbuk

\section{INTRODUCTION}

Titanium dioxide (titania, $\mathrm{TiO}_{2}$ ) is the most commonly employed of the n-type semiconductors due to its high photoactivity and stability, relatively low cost, and non-toxicity. $\mathrm{TiO}_{2}$ is widely employed in various applications, especially in photocatalyst [1-3], antibacterial [4-6] and photovoltaic devices [7-9], superhydrophilic and light-induced amphiphilic surfaces [1012].

* Corresponding author.

Email address : sutrisnohari@uny.ac.id

DOI: 10.22146/ijc.28892

Hari Sutrisno et al. 
Titanium dioxide has eleven different structure phases (allotropes): anatase, rutile, brookite, $\mathrm{TiO}_{2}(\mathrm{~B})$, $\mathrm{TiO}_{2}(\mathrm{H})$-hollandite, $\mathrm{TiO}_{2}(\mathrm{R})$-ramsdellite, $\mathrm{TiO}_{2}$-columbite ( $\alpha-\mathrm{PbO}_{2}$ type, $\left.\mathrm{TiO}_{2}-\mathrm{II}\right)$, $\mathrm{TiO}_{2}$-baddeleyite $\left(\mathrm{TiO}_{2}-\mathrm{MI}\right), \mathrm{TiO}_{2}-$ orthorhombic $\left(\mathrm{TiO}_{2}-\mathrm{Ol}\right), \mathrm{TiO}_{2}$-fluorite $\left(\mathrm{CaF}_{2}\right.$ type), and $\mathrm{TiO}_{2}$-cotunnite. Three of these crystalline forms of $\mathrm{TiO}_{2}$ occur in nature as mineral: anatase (tetragonal, $14_{1} / \mathrm{amd}$ ) [13], rutile (tetragonal, $\boldsymbol{P} 4_{2} / \mathrm{mnm}$ ) [13], and brookite (orthorhombic, Pbca) [14], but only rutile and anatase have been able to be synthesized in pure form at low temperature until recent days.

A semiconductor is characterized by the presence of band energetic structure, with a band gap between the lower, valence band (VB) and the higher energetic, conduction band (CB). Electrons present in the occupied band (VB) are photoexcited and move to the CB, leaving a positive charged hole $\left(\mathrm{h}^{+}\right)$, when the semiconductor is photo-irradiated by light with photon energy (hv) at least equal to the band gap. Once formed, the electron $\left(\mathrm{e}^{-}\right)$ and hole $\left(\mathrm{h}^{+}\right)$pair may undergo either fast recombination. A photocatalytic reaction will occur that leads to the development of useful processes. Anatase shows a band gap of $3.2 \mathrm{eV}$, corresponding to a UV wavelength adsorption of $387 \mathrm{~nm}$ [15]. In contrast, rutile has a smaller band gap $(3.0 \mathrm{eV})$, with excitation wavelengths that extend into the visible light range (410 $\mathrm{nm}$ ) [16] and the band gap of the metastable brookite is $3.54 \mathrm{eV}$ [17]. Many metal ions are used as dopant to increase the $\lambda$ radiation adsorption, such as niobium [18], argentum [19-20], vanadium [21], ferrum [22], zinc [23], and chromium [24-26].

$X$-ray diffraction is the most useful technique for qualitative and quantitative phase analysis in multiphase. Qualitative analysis identifies phases in a specimen compared to "standard" patterns such as American Society for Testing and Materials (ASTM), Joint Committee on Powder Diffraction Standards (JCPDS), Crystallography Open Database (COD), Inorganic Crystal Structure Database (ICSD) and International Centre for Diffraction Data (ICDD). X-ray diffraction pattern gives information about peak positions, intensity, and shape. Qualitative analysis of powder diffraction data is the identification of crystal phase, peak position and intensity related to unique crystal structure. Quantitative analysis of powder diffraction data refers to the determination of amounts of different phases in multi-phase samples. Quantification can be carried out because the intensity of the diffraction pattern of a phase or phases in a mixture depends on its concentration. There are several methods of X-ray diffraction to quantify phases such as direct comparison, internal standard, external standard, absorptiondiffraction, reference intensity ratio $(\mathrm{RIR})$ and wholepattern fitting (Rietveld analysis) [27-30].
The objectives of this research are (1) qualitative phase analysis in undoped titanium dioxide and a series of chromium doped $\mathrm{TiO}_{2}$ compared to "standard" patterns: COD and ICDD, (2) analysis of quantitative phase in the samples by comparing two methods: RIR and whole-pattern fitting (Rietveld analysis). This research is important to know the precise and accurate method of qualitative and quantitative analysis in determining the crystalline phases contained in a sample of $\mathrm{Cr}$ doped $\mathrm{TiO}_{2}$ solid solutions.

\section{EXPERIMENTAL SECTION}

\section{Materials}

Ammonium hydroxide $\left(\mathrm{NH}_{4} \mathrm{OH}, \quad 28-30 \% \quad \mathrm{NH}_{3}\right)$ solution, hydrogen peroxide $\left(\mathrm{H}_{2} \mathrm{O}_{2}, 10 \%\right.$ wt in $\left.\mathrm{H}_{2} \mathrm{O}\right)$, ammonium chromate $\left.\left(\mathrm{NH}_{4}\right)_{2} \mathrm{CrO}_{4}, 99 \%\right)$, titanium (IV) chloride $\left(\mathrm{TiCl}_{4}, 99 \%\right)$ were purchased from SigmaAldrich. All the reagents were used without further purification. Titanium dioxide hydrate $\left(\mathrm{Ti}\left(\mathrm{O}_{2}\right) \mathrm{O}_{2} .2 \mathrm{H}_{2} \mathrm{O}\right)$ was obtained from the reaction of $\mathrm{TiCl}_{4}$ and $\mathrm{H}_{2} \mathrm{O}_{2}$ [31]. A series of chromium(III) doped $\mathrm{TiO}_{2}$ with various \%wt $\mathrm{Cr}$ atom were prepared by the reflux technique. In a typical synthesis, $10 \mathrm{~g} \mathrm{Ti}\left(\mathrm{O}_{2}\right) \mathrm{O} .2 \mathrm{H}_{2} \mathrm{O}$ is dissolved in 50 $\mathrm{mL}$ of distilled water under vigorous stirring. The solution was kept stirring for $4 \mathrm{~h}$ to obtain colloid $\mathrm{A}$. In order to investigate the effect of the $\left(\mathrm{NH}_{4}\right)_{2} \mathrm{CrO}_{4}$ concentration, in a separated beaker $0,3,6$, and $9 \% \mathrm{wt}$ Cr-doped $\mathrm{TiO}_{2}$ respectively were adopted. It was dissolved in $20 \mathrm{~mL}$ of distilled water thoroughly under vigorous stirring to obtain solution $\mathrm{B} 1, \mathrm{~B} 2, \mathrm{~B} 3$, and $\mathrm{B} 4$, respectively. Each solution B1, B2, B3 and B4 was then slowly added to each solution $A$. The final solution mixture was sealed and further stirred for $2 \mathrm{~h}$, then added dropwise $\mathrm{NH}_{4} \mathrm{OH}$ until $\mathrm{pH} \approx 8-10$. Finally the solution is heated with a magnetic stirrer in equipment reflux at $150{ }^{\circ} \mathrm{C}$ for $6 \mathrm{~h}$. Precipitate is filtered, washed with distilled water and dried at $70{ }^{\circ} \mathrm{C}$ for $3 \mathrm{~h}$. Furthermore, the precipitate was calcined at $600{ }^{\circ} \mathrm{C}$ for $2 \mathrm{~h}$.

\section{Instrumentation}

In order to obtain XRD powder data, a Rigaku Miniflex 600-Benchtop diffractometer with a copper tube and Ka radiation of $\lambda=1.5406 \AA$, operating at 40 $\mathrm{kV}$ and $15 \mathrm{~mA}$, was used. The samples were mounted in a silica glass sample holder. The powder XRD data were collected in the $2 \theta$ interval ranging from $2^{\circ}$ to $90^{\circ}$ with a step width of $0.02^{\circ}$ and a counting time of 5 sec/step.

Scanning electron microscope (Phenom ProX Desktop SEM) equipped with energy dispersive X-ray spectroscopy (EDS) was used to analyze the presence 
of $\mathrm{Ti}$ and $\mathrm{O}$ elements in the $\mathrm{TiO}_{2}$ and the presence of $\mathrm{Ti}$, $\mathrm{Cr}$, and $\mathrm{O}$ elements in the $\mathrm{Cr}$-doped $\mathrm{TiO}_{2}$.

\section{Procedure}

\section{Qualitative phase analysis}

Diffraction patterns are unique "fingerprints" of the crystal structure of materials that can be used to determine phase composition of a polycrystalline material. Phase identification is essentially an exercise of pattern comparison between the unknown and a database of single-phase reference patterns. The qualitative analysis was carried out with the identification of a phase or phases in the samples by comparison with "standard" patterns: COD and ICDD.

\section{Quantitative phase analysis}

Quantitative analysis of diffraction data usually refers to the determination of amounts of different phases in multi-phase samples. The quantitative phase analysis was calculated by comparing two methods: reference intensity ratio (RIR) and whole-pattern fitting (Rietveld analysis).

Reference Intensity Ratio (RIR) method. The RIR is a method used for quantitative analysis by powder diffraction and is based upon scaling all diffraction data to the diffraction of standard reference materials. The RIR method can be used to determine concentrations by using ratios and measuring peak areas. Klug and Alexander were first to describe a technique for quantification using intensities of the crystalline phases in a mixture as in equation 1 [27]:

$\frac{\mathrm{I}_{(\mathrm{hkl}) \mathrm{A}}}{\mathrm{I}_{(\mathrm{hk}) \mathrm{B}}}=\mathrm{k} \frac{\mathrm{X}_{\mathrm{A}}}{\mathrm{X}_{\mathrm{B}}}$

where, ratio of peak intensity from unknown phase ' $A$ ' $\left(\mathrm{l}_{(\mathrm{hkl})}\right)$ to a standard ' $\mathrm{B}$ ' $\left(\mathrm{I}_{(\mathrm{hkl})}\right)$ is a linear function of the mass fraction of ' $A$ ' in the original sample and the amount of minerals in known internal standards (eg, rutile, silica) is used to calibrate unknown phase intensities.

ICDD PDF-2 uses corundum $\left(\mathrm{Al}_{2} \mathrm{O}_{3}\right)$ as reference $B$ and gives $k$ for 50:50 mixtures of phase $A$ and corundum. RIR is $1 / I_{\text {cor }}$ using intensity of the strongest peak $(100 \%)$, If $I_{1} / I_{\text {cor }}$ is $k_{1}$ and $I_{2} / I_{\text {cor }}$ is $k_{2}$, then $I_{1} / l_{2}$ is $k_{1} / k_{2}$. The RIR values or intensity ratio of the more intense peak of each phase respect to the (113) peak of corundum reported in the PDF of the ICDD is expressed as (2) [32]:

$\mathrm{w}_{1}=\frac{\mathrm{l}_{1}^{\mathrm{k}} \mathrm{w}_{\text {corrundum }}}{\mathrm{l}_{\text {corrundum }}^{113} \mathrm{RIR} \mathrm{R}_{1, \text { corrundum }}}$

where, $\mathbf{w}_{1}=$ weight fraction of phase 1 and $\mathbf{w}_{\text {corundum }}=$ weight fraction of corundum.
Whole-pattern fitting method (Rietveld analysis).

Rietveld (1969) developed a method to refine crystal structure information using neutron powder diffraction [32]. The Rietveld method is based on a least-squares fit between step-scan data of a measured diffraction pattern and a simulated X-raydiffraction pattern. The simulated XRD pattern is calculated from a large number of parameters, including crystal-structure parameters of each component phase, a scale factor for each constituent phase to adjust the relative intensities of the reflections, parameters describing the peak profile and the background, and parameters simulating the instrumental aberrations as well as effects resulting from size-related strain, preferred orientation, and particle size. A key feature of the quantitative analysis of phase proportions by the Rietveld method is that the phase abundances of the constituent phases can be directly calculated from the refined scale-factors. To refine each XRD spectrum in the research, The Rietveld analysis was applied by using Fullprof software by Roisnel and Rodriguez Carbajal on the package WinPlotr [33]. In the refinement procedure, a calculated pattern is fitted to an observed diffraction pattern by the least-squares method, until the best fit is obtained. The least-squares refinement leads to a minimal residual quantity $\left(\chi^{2}\right)$ in the Rietveld Method [34] is,

$\chi^{2}=\sum_{i=1}^{n} w_{i}\left\{y_{i}-y_{c, i}(\alpha)\right\}^{2}$

with $w_{i}=1 / \sigma_{i}^{2}$, being $\sigma_{i}{ }^{2}$ the variance of the "observation" $y_{i}, y_{i}=$ observed intensity at the $i^{\text {th }}$ step, and $y_{c, i}=$ calculated intensity at the $i^{\text {th }}$ step. The calculated profile of X-ray powder pattern can be well described by the equation:

$\mathrm{y}_{\mathrm{c}, \mathrm{i}}=\sum_{\phi} \mathrm{s}_{\phi} \sum_{\mathrm{h}} \mathrm{l}_{\phi, \mathrm{h}} \Omega\left(\mathrm{T}_{\mathrm{i}}-\mathrm{T}_{\phi, \mathrm{h}}\right)+\mathrm{b}_{\mathrm{i}}$

In Fullprof, the term phase is synonymous of a same procedure for calculating the integrated intensities $\left(\mathbf{I}_{\phi, h}\right)$. Rietveld phase quantification (sometimes called also standardless phase analysis, multiphase Rietveld quantitative analysis or Rietveld XRD quantification) is a powerful method for determining the quantities of crystalline and amorphous components in multiphase mixtures. The weight fraction $\left(\mathrm{W}_{\mathrm{i}}\right)$ for each phase was obtained from the refinement relation [34]:

$W_{i}=\frac{s_{i}(Z M V)_{i}}{\sum_{j} s_{j}(Z M V)_{j}}$

where $i$ is the value of $j$ for a particular phase among the $\mathrm{N}$ phases present. The $\mathrm{S}, \mathrm{Z}, \mathrm{M}$, and $\mathrm{V}$ are, respectively, the Rietveld scale factor, the number of 


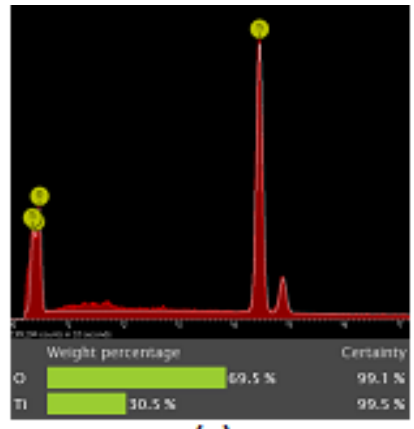

(a)

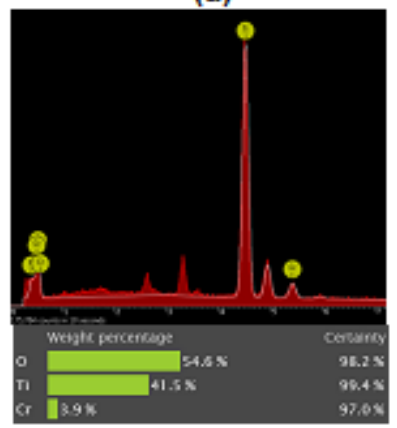

(c)

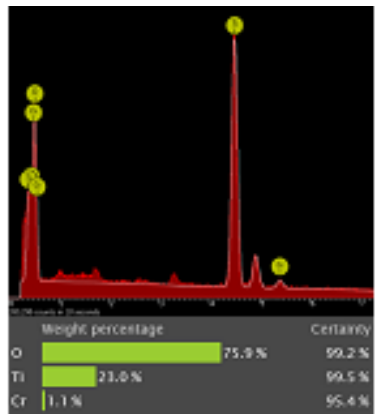

(b)

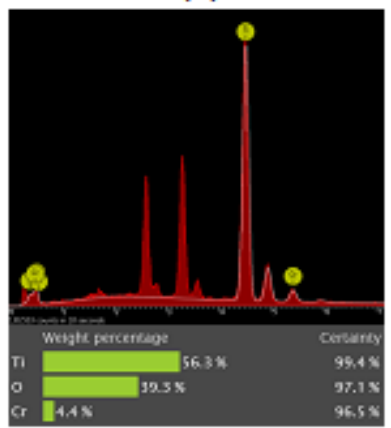

(d)
Fig 1. EDS analysis and weight percentage of $\mathrm{Ti}, \mathrm{O}$ and $\mathrm{Cr}$ of (a). undoped $\mathrm{TiO}_{2}$, (b). $1.1 \%$ wt Cr-doped $\mathrm{TiO}_{2}$, (c). $3.9 \%$ wt Cr-doped $\mathrm{TiO}_{2}$, and (d). $4.4 \%$ wt Cr-doped $\mathrm{TiO}_{2}$

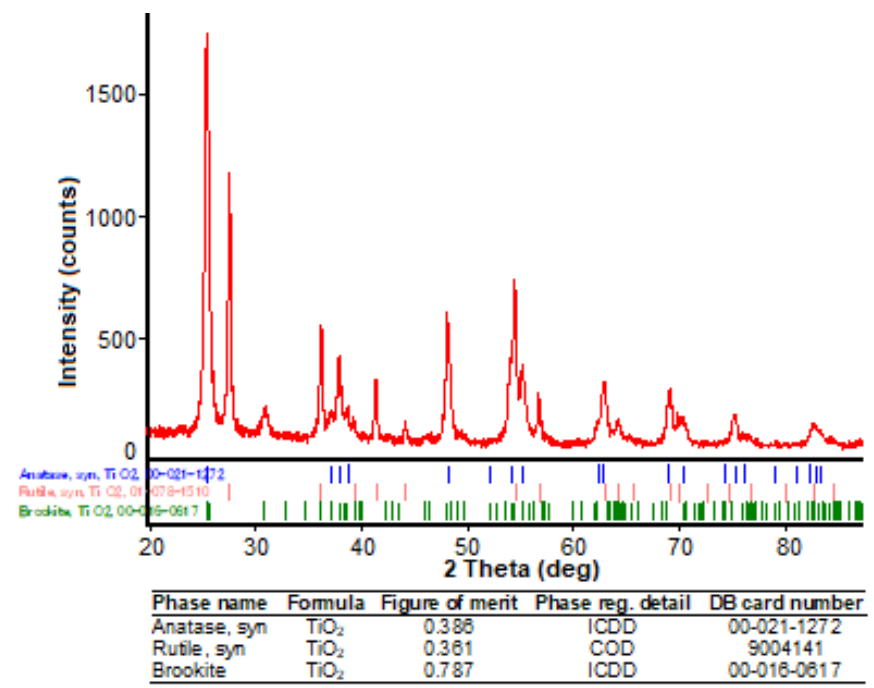

Fig 2. XRD diagram and the result of qualitative analysis of undoped $\mathrm{TiO}_{2}$

formula units per cell, the mass of the formula unit (in atomic mass units) and the unit cell volume (in $\AA^{3}$ ). The fit must be evaluated by visual comparison between the observed and calculated pattern. The quality of the agreement between observed and calculated profiles is measured by a set of nowadays-conventional factors (profile factor $\left(R_{p}\right)$, weighted profile factor $\left(R_{w p}\right)$, expected

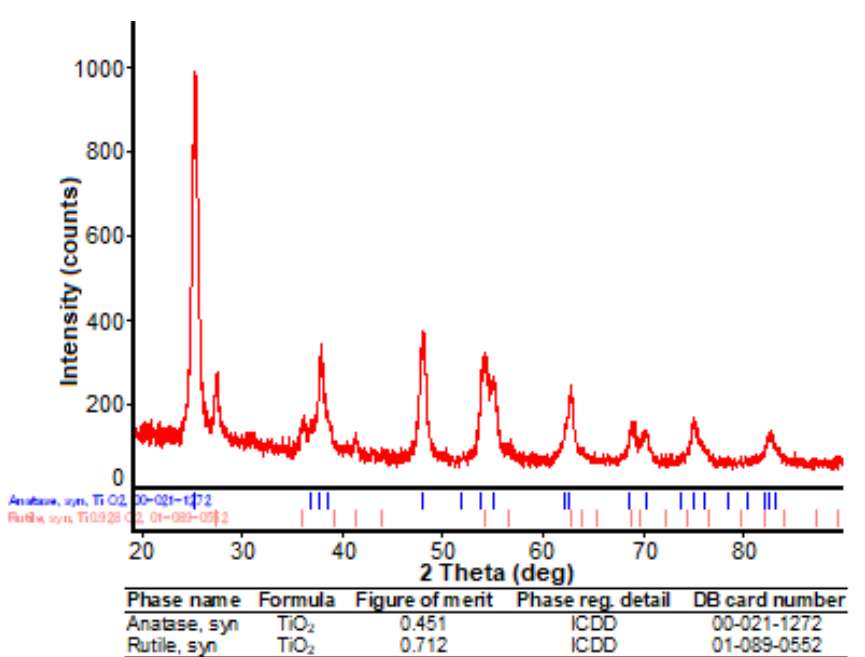

Fig 3. XRD diagram and the result of qualitative analysis of $1.1 \%$ wt $\mathrm{Cr}$-doped $\mathrm{TiO}_{2}$

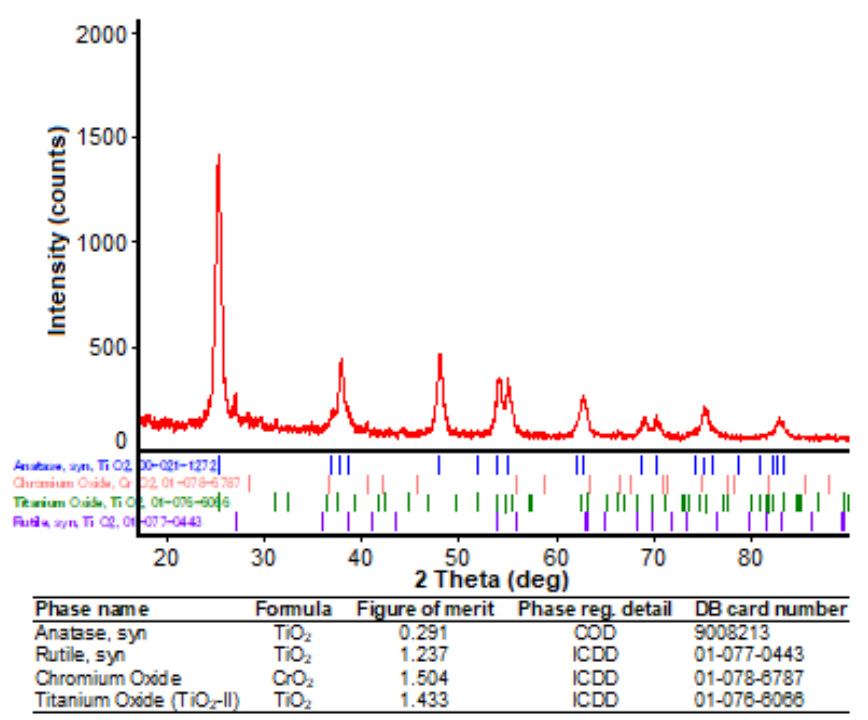

Fig 4. XRD diagram and the result of qualitative analysis of $3.9 \%$ wt $\mathrm{Cr}$-doped $\mathrm{TiO}_{2}$

weighted profile Ffactor (Rexp), and goodness of fit indicator (GoF)).

\section{RESULT AND DISCUSSION}

\section{EDS Analysis}

The scanning electron microscopy-energy dispersive X-ray spectroscopy (SEM-EDS) analysis reveals the presence of $\mathrm{Ti}$ and $\mathrm{O}$ elements in undoped $\mathrm{TiO}_{2}$ and of $\mathrm{Ti}, \mathrm{Cr}$, O elements in various \%wt $\mathrm{Cr}$-doped $\mathrm{TiO}_{2}$. On the theoretical, addition of each: 3,6 and 9 $\%$ wt $\mathrm{Cr}$-doped $\mathrm{TiO}_{2}$ produced experimentally only 1.1 , 3.9 and $4.4 \%$ wt Cr-doped $\mathrm{TiO}_{2}$ respectively (Fig. 1). 
Based on the composition of the atoms, the molecular formula of solid solutions $\left(\mathrm{Ti}_{1-\mathrm{x}} \mathrm{Cr}_{\mathrm{x}} \mathrm{O}_{2}\right)$ for $1.1,3.9$ and 4.4 \%wt Cr-doped $\mathrm{TiO}_{2}$ are $\mathrm{Ti}_{0.983} \mathrm{Cr}_{0.017} \mathrm{O}_{2}, \mathrm{Ti}_{0.940} \mathrm{Cr}_{0.060} \mathrm{O}_{2}$, and $\mathrm{Ti}_{0.932} \mathrm{Cr}_{0.068} \mathrm{O}_{2}$, respectively.

\section{Qualitative Phase Analysis}

Fig. 2, 3, 4 and 5 show XRD patterns of undoped $\mathrm{TiO}_{2}$ and $\mathrm{Cr}$-doped $\mathrm{TiO}_{2}$ at various \%wt $\mathrm{Cr}$ atom. All XRD patterns exhibit strong diffraction peaks at $2 \theta$ : 25.36 , $37.84,48.11,54.38,55.07$, and $62.88^{\circ}$ indicating $\mathrm{TiO}_{2}$ of anatase phase and at $2 \theta: 27.53,36.14,41.32$, and 54.38 indicating $\mathrm{TiO}_{2}$ of rutile phase. The main diffraction peaks are indexed as the (101), (103), (200), (105), (211), (213) reflections of crystalline anatase phase, corresponding to those shown in the ICDD card No. 00021-1272 and the main diffraction peaks are indexed as the (110), (101), (200), (111), (211) reflections of crystalline rutile phase, corresponding to those shown in the COD card No. 9004141. In the undoped $\mathrm{TiO}_{2}$, there are three phases: anatase, rutile, and brookite (Fig. 2). Fig. 3 shows that the $1.1 \% w t \mathrm{Cr}$-doped $\mathrm{TiO}_{2}$ sample is detected presenting two phases of $\mathrm{TiO}_{2}$ : anatase (major) and rutile (minor). In the $3.9 \%$ wt Cr-doped $\mathrm{TiO}_{2}$ (Fig. 4) and the $4.4 \%$ wt $\mathrm{Cr}$-doped $\mathrm{TiO}_{2}$ (Fig. 5) show the presence of anatase (major), rutile (minor), chromium

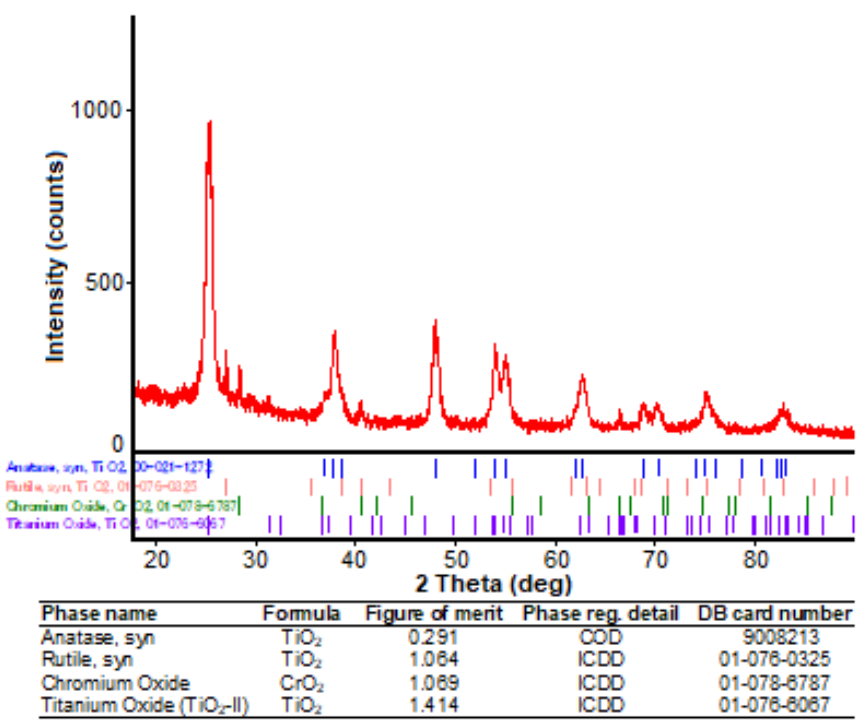

Fig 5. XRD diagram and the result of qualitative analysis of $4.4 \%$ wt $\mathrm{Cr}$-doped $\mathrm{TiO}_{2}$

Table 1. Phase content of $\mathrm{TiO}_{2}$ and (hkl) in undoped $\mathrm{TiO}_{2}$ and various \%wt $\mathrm{Cr}$-doped $\mathrm{TiO}_{2}$

\begin{tabular}{|c|c|c|c|c|c|c|c|c|}
\hline \multicolumn{4}{|c|}{ Samples } & \multicolumn{5}{|c|}{ (hkl) planes } \\
\hline $\begin{array}{c}\text { Undoped } \\
\mathrm{TiO}_{2}\end{array}$ & $\begin{array}{c}1.1 \% w t \\
\text { Cr-doped } \\
\mathrm{TiO}_{2}\end{array}$ & $\begin{array}{c}3.9 \% w t \\
\text { Cr-doped } \\
\mathrm{TiO}_{2}\end{array}$ & $\begin{array}{c}4.4 \% w t \\
\text { Cr-doped } \\
\mathrm{TiO}_{2}\end{array}$ & Anatase & Rutile & Brookite & $\mathrm{CrO}_{2}$ & $\mathrm{TiO}_{2}-\mathrm{II}$ \\
\hline 25.36 & 25.29 & $\begin{array}{l}25.31 \\
27.10\end{array}$ & $\begin{array}{l}25.33 \\
27.06\end{array}$ & (101) & & (210) & (011) & (110) \\
\hline 27.53 & 27.39 & 28.39 & 28.39 & & (110) & & (110) & \\
\hline $\begin{array}{l}30.95 \\
36.14\end{array}$ & 36.04 & 31.24 & 31.29 & & (101) & (211) & & (111) \\
\hline $\begin{array}{l}37.05 \\
37.84\end{array}$ & 37.76 & 36.90 & 36.94 & $\begin{array}{l}(103) \\
(004)\end{array}$ & & & & \\
\hline $\begin{array}{l}38.04 \\
38.67 \\
39.24\end{array}$ & 37.80 & 37.82 & 37.93 & (112) & (200) & $\begin{array}{l}(311) \\
(220) \\
(400)\end{array}$ & & \\
\hline $\begin{array}{l}41.32 \\
44.13\end{array}$ & 41.34 & 40.54 & 40.43 & & $\begin{array}{l}(200) \\
(111) \\
(210)\end{array}$ & & (020) & \\
\hline 48.11 & $\begin{array}{l}48.00 \\
53.98\end{array}$ & $\begin{array}{l}48.01 \\
53.99\end{array}$ & $\begin{array}{l}48.01 \\
53.96\end{array}$ & (200) & & (402) & & \\
\hline $\begin{array}{l}54.38 \\
55.07 \\
56.63\end{array}$ & 55.10 & 55.04 & 55.02 & $\begin{array}{l}(105) \\
(211)\end{array}$ & $\begin{array}{l}(211) \\
(220)\end{array}$ & & & \\
\hline $\begin{array}{l}62.88 \\
64.13\end{array}$ & 62.79 & 62.75 & 62.72 & (213) & $\begin{array}{l}(002) \\
(310)\end{array}$ & (023) & & \\
\hline $\begin{array}{l}68.96 \\
69.85\end{array}$ & 68.87 & 68.95 & $\begin{array}{l}66.38 \\
68.77\end{array}$ & (116) & $\begin{array}{l}(301) \\
(112)\end{array}$ & & & (023) \\
\hline 70.34 & 70.19 & 70.20 & 70.08 & (220) & & & & \\
\hline $\begin{array}{l}75.06 \\
75.98\end{array}$ & 74.94 & 75.04 & 75.02 & $\begin{array}{l}(215) \\
(301)\end{array}$ & & & & \\
\hline 82.54 & 82.57 & 82.78 & 82.63 & (224) & (321) & $(440)$ & & \\
\hline
\end{tabular}


Table 2. Phase content of $\mathrm{TiO}_{2}$ in undoped $\mathrm{TiO}_{2}$ and various \%wt Cr-doped $\mathrm{TiO}_{2}$ calculated using RIR method

\begin{tabular}{|c|c|c|c|c|c|}
\hline \multirow{2}{*}{ Samples } & \multicolumn{5}{|c|}{ Phase (\%) } \\
\hline & Anatase & Rutile & Brookite & $\mathrm{CrO}_{2}$ & $\mathrm{TiO}_{2}-\mathrm{II}$ \\
\hline UndopedTiO2 & 52.2 & 25.1 & 22.7 & - & \\
\hline $1.1 \%$ wt $\mathrm{Cr}$-doped $\mathrm{TiO}_{2}$ & 87.0 & 13.0 & - & - & \\
\hline $3.9 \%$ wt $\mathrm{Cr}$-doped $\mathrm{TiO}_{2}$ & 91.0 & 2.8 & - & 2.7 & 3.3 \\
\hline $4.4 \%$ wt $\mathrm{Cr}$-doped $\mathrm{TiO}_{2}$ & 96.0 & 2.2 & - & 1.4 & 0.4 \\
\hline
\end{tabular}

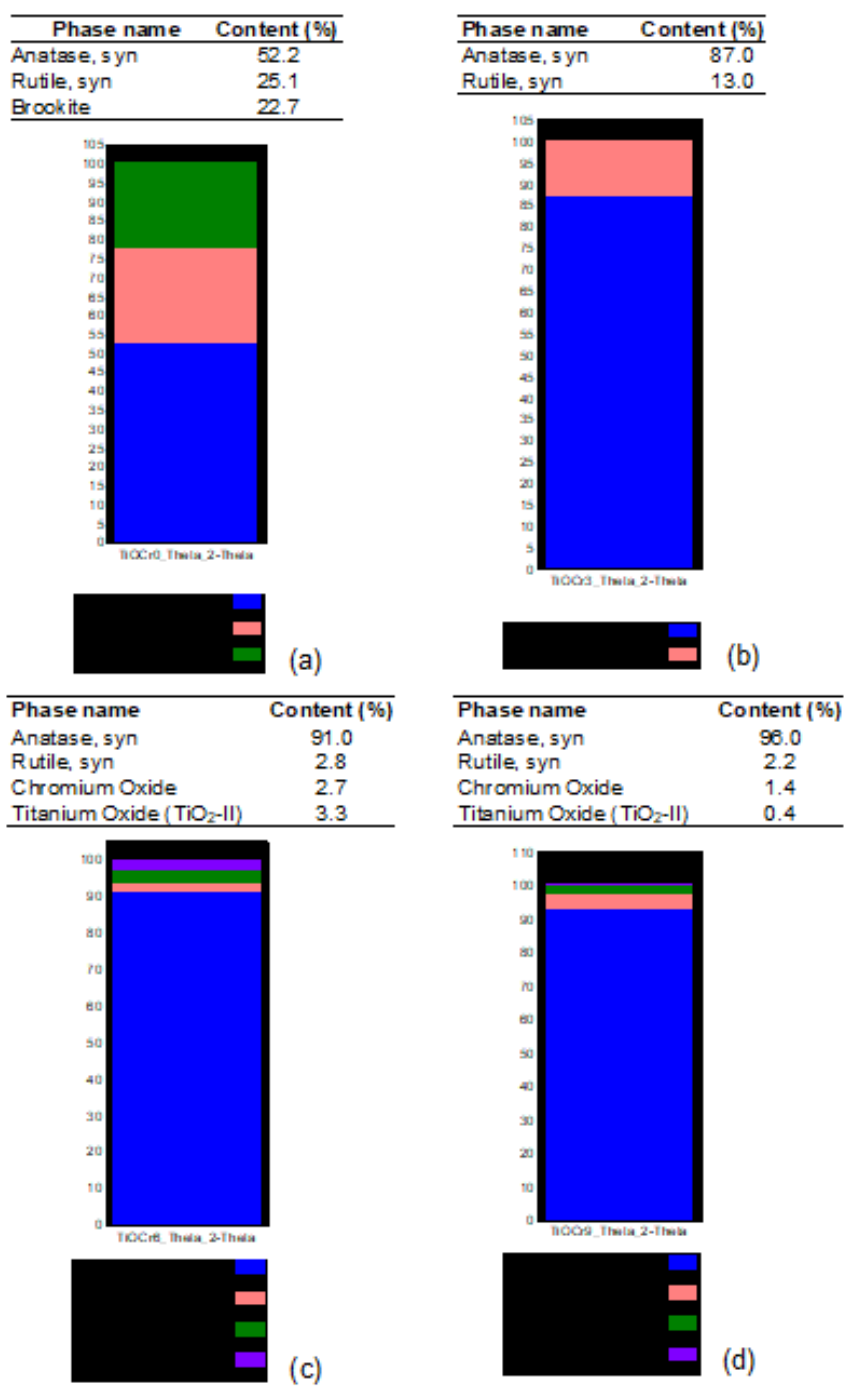

Fig 6. Composition XRD diagram of (a). undoped $\mathrm{TiO}_{2}$, (b). $1.1 \%$ wt Cr-doped $\mathrm{TiO}_{2}$, (c). $3.9 \%$ wt Cr-doped $\mathrm{TiO}_{2}$, and (d). $4.4 \%$ wt Cr-doped $\mathrm{TiO}_{2}$

oxide (minor) and $\mathrm{TiO}_{2}-\mathrm{Il}$ (minor). The results of identification of a phase or phases and (hkl) in the samples are showed in Table 1.

\section{Quantitative Phase Analysis}

\section{RIR method}

Fig. 6 shows the weight fraction of $\mathrm{TiO}_{2}$ phases calculated using the RIR method. The phase content of all samples calculated by RIR method are showed in Table 2. In the undoped $\mathrm{TiO}_{2}$ shows the following phase compositions: anatase $(52.2 \%)$, rutile $(25.1 \%)$ and brookite $(22.7 \%)$, while in the $1.1 \%$ wt Cr-doped $\mathrm{TiO}_{2}$, its phase composition are anatase (87.0\%) and rutile $(13.0 \%)$. The chromium oxide, rutile and $\mathrm{TiO}_{2}-\mathrm{II}$ present in the $3.9 \%$ wt $\mathrm{Cr}$-doped $\mathrm{TiO}_{2}$ and the $4.4 \%$ wt Cr-doped $\mathrm{TiO}_{2}$, respectively. In the $3.9 \%$ wt Cr-doped $\mathrm{TiO}_{2}$ are detected $91.0 \%$ of anatase, $2.8 \%$ of rutile, $2.7 \%$ of $\mathrm{CrO}_{2}$, and $3.3 \%$ of $\mathrm{TiO}_{2}-\mathrm{Il}$, while in the $4.4 \%$ wt Cr-doped $\mathrm{TiO}_{2}$ consist of $96.0 \%$ of anatase, $2.2 \%$ of rutile, $1.4 \%$ of $\mathrm{CrO}_{2}$, and $0.4 \%$ of $\mathrm{TiO}_{2}-\mathrm{II}$.

\section{Whole-pattern fitting method (Rietveld analysis)}

$X$-ray diffraction-Rietveld refinement was carried out with the method supplied by the Fullprof software to undoped $\mathrm{TiO}_{2}$ and various \%wt $\mathrm{Cr}$-doped $\mathrm{TiO}_{2}$. The results of Rietveld refinement are shown in Fig. 7, 8, 9 and 10. The experimental points are given as dot (.) and theoretical data (calculated by eq. (3)) are shown as solid line. Difference between experimental data and theoretical is shown as bottom line. The vertical lines represent the Bragg's allowed peaks. In the undoped $\mathrm{TiO}_{2}$ were refined in the crystal system and space group of anatase (tetragonal, $14_{1} / \mathrm{amd}$ ), rutile (tetragonal, $\boldsymbol{P} 4_{2} / \mathrm{mnm}$ ) and brookite (orthorhombic, Pbca) (Fig. 7). No reflections of anatase (major) and rutile (minor) phases are observed in the $1.1 \%$ wt $\mathrm{Cr}$ doped $\mathrm{TiO}_{2}$ (fig. 8) and it's were refined in the crystal system and space group of anatase (tetragonal, I41/amd), and rutile (tetragonal, $\boldsymbol{P} 4_{2} / \mathrm{mnm}$ ). In the 3.9 \%wt Cr-doped $\mathrm{TiO}_{2}$ and $4.4 \% w t$ Cr-doped $\mathrm{TiO}_{2}$ respectively consist of anatase phase, while rutile, chromium dioxide and $\mathrm{TiO}_{2}$-II phases can't be detected by Rietveld refinements. Fig. 9 and 10 depict Fullprof Pattern Matching of anatase phase in the $3.9 \%$ wt Crdoped $\mathrm{TiO}_{2}$ and $4.4 \%$ wt $\mathrm{Cr}$ - doped $\mathrm{TiO}_{2}$ respectively. The results of crystal system, cell parameters (a, b, c) and atomic position $(\mathrm{x}, \mathrm{y}, \mathrm{z})$ are presented in Table 3 .

Fig. 11 shows the relationship between cell volumes of anatase at various \%wt $\mathrm{Cr}$ atom of $\mathrm{Cr}$ doped $\mathrm{TiO}_{2}$. The cell volume of anatase crystals have increased with increasing \%wt $\mathrm{Cr}$ atoms of $\mathrm{Cr}$ doped $\mathrm{TiO}_{2}$. This is due to the replacement of $\mathrm{Ti}(\mathrm{IV})$ ions which have crystal radii of $0.746 \AA$ replaced by $\mathrm{Cr}(\mathrm{III})$ ions having larger crystal radii that is $0.755 \AA$ [35]. 
Table 3. The crystal system, cell parameters $(a, b, c)$ and atomic position $(x, y, z)$ of $\mathrm{TiO}_{2}$ phases in undoped $\mathrm{TiO}_{2}$ and various \%wt $\mathrm{Cr}$-doped $\mathrm{TiO}_{2}$ calculated by Rietveld method

\begin{tabular}{|c|c|c|c|c|c|c|c|c|c|}
\hline Samples & Phase & $\begin{array}{l}\mathrm{a} \\
(\AA ̊ \AA)\end{array}$ & $\begin{array}{l}\mathrm{b} \\
(\AA)\end{array}$ & $\begin{array}{l}\mathrm{C} \\
(\AA)\end{array}$ & $\begin{array}{l}\mathrm{V} \\
\left(\AA^{3}\right)\end{array}$ & Atom & $x$ & $y$ & z \\
\hline \multirow{5}{*}{$\begin{array}{l}\text { Undoped } \\
\mathrm{TiO}_{2}\end{array}$} & Anatase & \multirow[b]{2}{*}{3.7819} & \multirow[b]{2}{*}{3.7819} & \multirow[b]{2}{*}{9.5008} & \multirow[b]{2}{*}{135.89} & $\mathrm{Ti}^{+4}$ & 0.0000 & 0.0000 & 0.5000 \\
\hline & $\begin{array}{l}\text { Tetragonal, } \\
\left(4_{1} / a m d\right)\end{array}$ & & & & & $\mathrm{O}^{-2}$ & 0.0000 & -0.5000 & 0.5447 \\
\hline & Rutile & \multirow[b]{2}{*}{4.5901} & \multirow[b]{2}{*}{4.5901} & \multirow[b]{2}{*}{2.9553} & \multirow[b]{2}{*}{62.26} & $\mathrm{Ti}^{+4}$ & 0.0000 & 0.0000 & 0.0000 \\
\hline & $\begin{array}{l}\text { (Tetragonal, } \\
P 4_{2} / m n m \text { ) }\end{array}$ & & & & & $\mathrm{O}^{-2}$ & 0.3064 & 0.3064 & 0.0000 \\
\hline & $\begin{array}{l}\text { Brookite } \\
\text { (Orthorhombic, } \\
\text { Pbca) } \\
\text { Anatase }\end{array}$ & 9.1601 & 5.4291 & 5.1476 & 255.99 & $\begin{array}{l}\mathrm{Ti}^{+4} \\
\mathrm{O}_{1}^{-2} \\
\mathrm{O}_{2}^{-2} \\
\mathrm{Ti}^{-4}\end{array}$ & $\begin{array}{l}0.1292 \\
0.0331 \\
0.2136 \\
0.0000\end{array}$ & $\begin{array}{l}0.0912 \\
0.1830 \\
0.0949 \\
0.0000\end{array}$ & $\begin{array}{l}0.8658 \\
0.1427 \\
0.5469 \\
0.5000\end{array}$ \\
\hline \multirow{3}{*}{$\begin{array}{l}1.1 \% \text { wt } \mathrm{Cr}- \\
\text { doped } \mathrm{TiO}_{2}\end{array}$} & $\begin{array}{l}\text { (Tetragonal, } \\
14_{1} / a m d \text { ) }\end{array}$ & 3.7930 & 3.7930 & 9.5075 & 136.78 & $\mathrm{O}^{-2}$ & 0.0000 & -0.5000 & 0.5447 \\
\hline & $\begin{array}{l}\text { 141/am } \\
\text { Rutile }\end{array}$ & \multirow[b]{2}{*}{4.5925} & \multirow[b]{2}{*}{4.5925} & \multirow[b]{2}{*}{2.9574} & \multirow[b]{2}{*}{62.37} & $\mathrm{Ti}^{+4}$ & 0.0000 & 0.0000 & 0.0000 \\
\hline & $\begin{array}{l}\text { (Tetragonal, } \\
\left.P 4_{2} / m n m\right)\end{array}$ & & & & & $\mathrm{O}^{-2}$ & 0.3041 & 0.3041 & 0.0000 \\
\hline \multirow{2}{*}{$\begin{array}{l}3.9 \% \text { wt } \mathrm{Cr}- \\
\text { doped } \mathrm{TiO}_{2}\end{array}$} & Anatase & \multirow[b]{2}{*}{3.7978} & \multirow[b]{2}{*}{3.7978} & \multirow[b]{2}{*}{9.5205} & \multirow[b]{2}{*}{137.32} & $\mathrm{Ti}^{+4}$ & 0.0000 & 0.0000 & 0.5000 \\
\hline & $\begin{array}{l}\text { (Tetragonal, } \\
14_{1} / \text { amd) }\end{array}$ & & & & & $\mathrm{O}^{-2}$ & 0.0000 & -0.5000 & 0.5405 \\
\hline \multirow{2}{*}{$\begin{array}{l}4.4 \% w t \mathrm{Cr}- \\
\text { doped } \mathrm{TiO}_{2}\end{array}$} & Anatase & \multirow[b]{2}{*}{3.7972} & \multirow[b]{2}{*}{3.7972} & \multirow[b]{2}{*}{9.5159} & \multirow[b]{2}{*}{137.21} & $\mathrm{Ti}^{+4}$ & 0.0000 & 0.0000 & 0.5000 \\
\hline & $\begin{array}{l}\text { (Tetragonal, } \\
14_{1} / a m d \text { ) }\end{array}$ & & & & & $\mathrm{O}^{-2}$ & 0.0000 & -0.5000 & 0.5347 \\
\hline
\end{tabular}

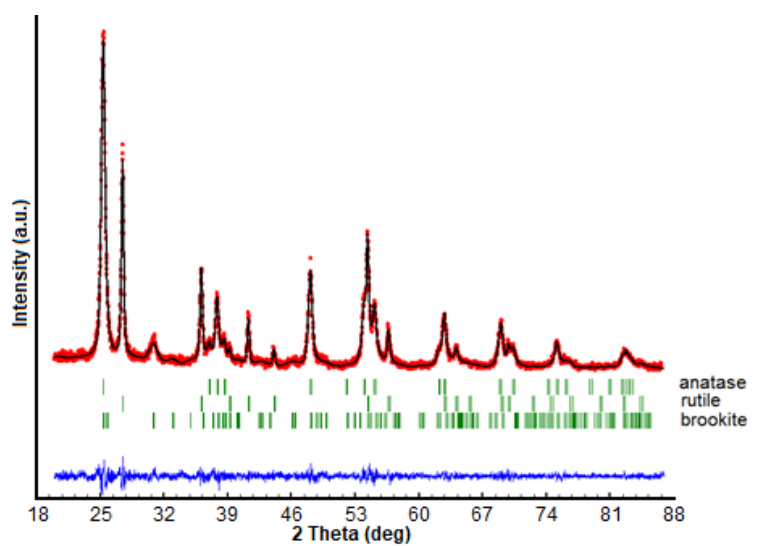

Fig 7. X-ray diffraction Fullprof Patern Matching of undoped $\mathrm{TiO}_{2}$

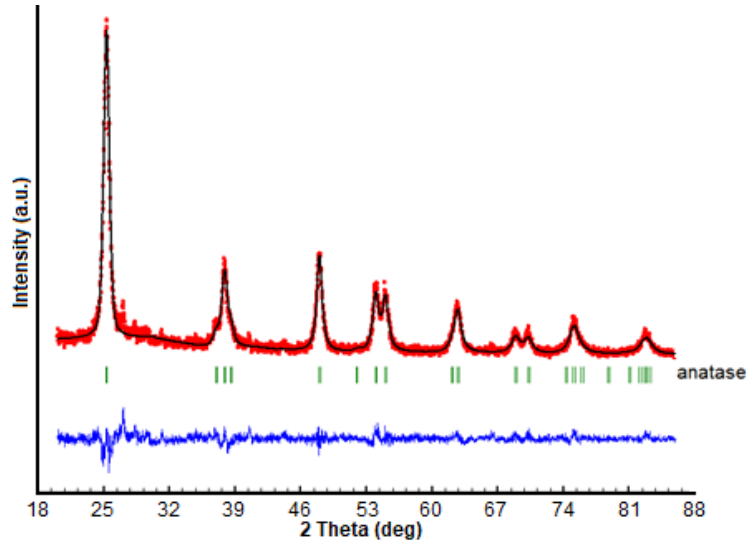

Fig 9. X-ray diffraction Fullprof Patern Matching of 3.9 $\%$ wt chromium doped $\mathrm{TiO}_{2}$

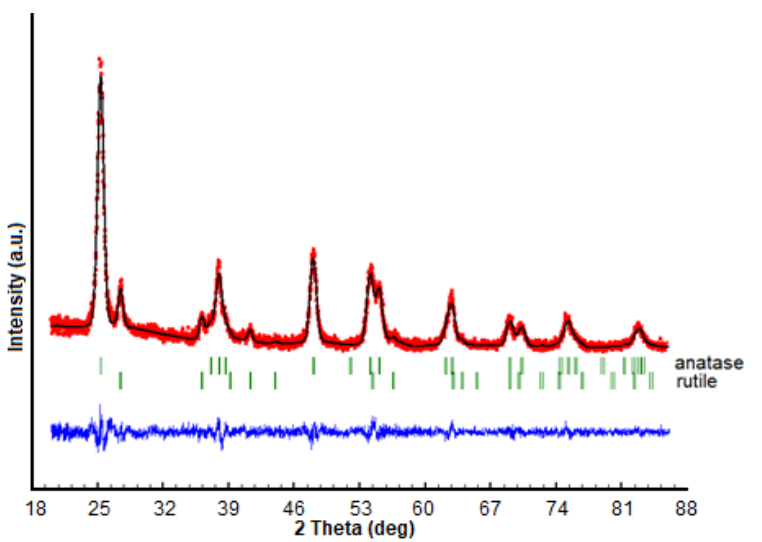

Fig 8. X-ray diffraction Fullprof Patern Matching of 1.1 $\%$ wt chromium doped $\mathrm{TiO}_{2}$

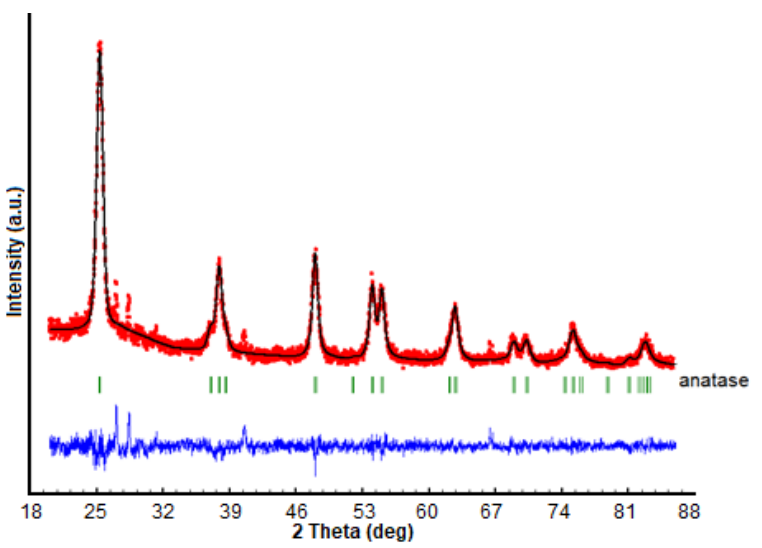

Fig 10. X-ray diffraction Fullprof Patern Matching of 4.4 $\%$ wt chromium doped $\mathrm{TiO}_{2}$ 
Table 4. Phase content of $\mathrm{TiO}_{2}$ in undoped $\mathrm{TiO}_{2}$ and various \%wt $\mathrm{Cr}$-doped $\mathrm{TiO}_{2}$ calculated using Rietveld method

\begin{tabular}{|c|c|c|c|c|c|c|c|c|c|}
\hline \multirow{2}{*}{ Samples } & \multicolumn{5}{|c|}{ Phase (\%) } & \multirow{2}{*}{$\begin{array}{l}R_{P} \\
(\%)\end{array}$} & \multirow{2}{*}{$\begin{array}{l}R_{w p} \\
(\%)\end{array}$} & \multirow{2}{*}{$\begin{array}{l}R_{\exp } \\
(\%)\end{array}$} & \multirow{2}{*}{ GoF } \\
\hline & Anatase & Rutile & Brookite & $\mathrm{CrO}_{2}$ & $\mathrm{TiO}_{2}-\mathrm{II}$ & & & & \\
\hline \multirow{4}{*}{$\begin{array}{l}\text { Undoped } \mathrm{TiO}_{2} \\
1.1 \% \text { wt } \mathrm{Cr}- \\
\text { doped } \mathrm{TiO}_{2} \\
3.9 \% \text { wt } \mathrm{Cr}- \\
\text { doped } \mathrm{TiO}_{2} \\
4.4 \% \text { wt } \mathrm{Cr}- \\
\text { doped } \mathrm{TiO}_{2}\end{array}$} & 49.58 & 38.39 & 12.03 & - & - & 7.02 & 9.06 & 8.37 & 1.08 \\
\hline & 88.45 & 11.50 & - & - & - & 7.53 & 9.72 & 9.43 & 1.03 \\
\hline & 100.00 & - & - & - & - & 7.84 & 10.30 & 8.69 & 1.18 \\
\hline & 100.00 & - & - & - & - & 8.20 & 11.10 & 8.88 & 1.25 \\
\hline
\end{tabular}

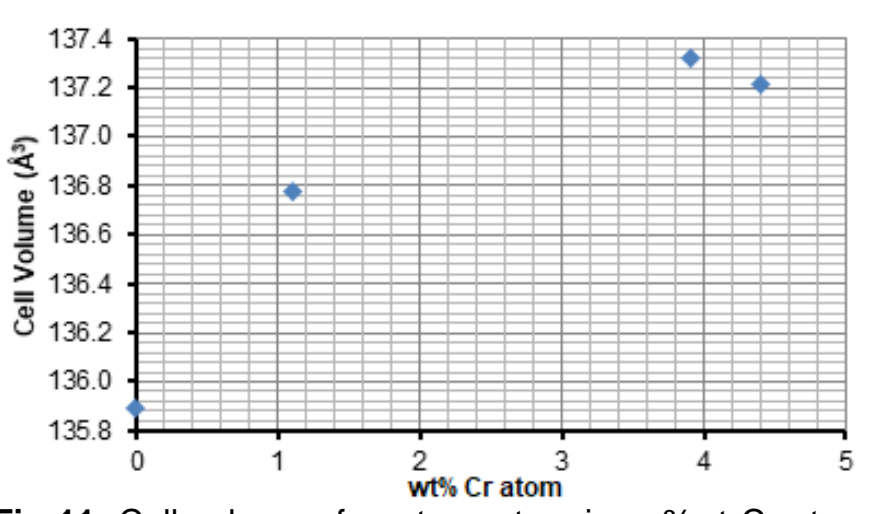

Fig 11. Cell volume of anatase at various \%wt $\mathrm{Cr}$ atom of $\mathrm{Cr}$-doped $\mathrm{TiO}_{2}$

The weight percentages of the phases were calculated by using the Rietveld method with the Fullprof software. Quantitative phase analysis obtained by Rietveld analysis by eq. (5). By the Rietveld refinement, the undoped $\mathrm{TiO}_{2}$ shows the following phase compositions: anatase $(49.58 \%)$, rutile $(38.39 \%)$ and brookite $(12.03 \%)$, while in the $1.1 . \%$ wt $\mathrm{Cr}$-doped $\mathrm{TiO}_{2}$, its phase composition are anatase $(88.45 \%)$ and rutile (11.50\%). In the $3.9 \%$ wt $\mathrm{Cr}$-doped $\mathrm{TiO}_{2}$ and $4.4 \%$ wt Crdoped $\mathrm{TiO}_{2}$ respectively consist of $100 \%$ of anatase phase, while rutile, chromium dioxide and $\mathrm{TiO}_{2}$-II phases can't be refined by Rietveld analysis. According to these results and the quality of the agreement between observed and calculated profiles, it can be saw that the handling of Table 4.

\section{CONCLUSION}

Undoped $\mathrm{TiO}_{2}$ and 1.1, 3.9, $4.4 \%$ wt $\mathrm{Cr}$-doped $\mathrm{TiO}_{2}$ have been successfully analyzed from powder x-ray diffraction data by qualitative and quantitative analysis using various method. Qualitative analysis was carried out with the identification of a phase or phases in the samples by comparison with "standard" patterns: COD and ICDD. In the undoped $\mathrm{TiO}_{2}$, three titania phases: anatase, rutile, and brookite were obtained. In the 1.1 $\%$ wt $\mathrm{Cr}$-doped $\mathrm{TiO}_{2}$ is detected presenting two phases of $\mathrm{TiO}_{2}$ : anatase (major) and rutile (minor), while anatase (major), rutile (minor), chromium oxide (minor) and $\mathrm{TiO}_{2}-$ II (minor) present in the $3.9 \%$ wt $\mathrm{Cr}$-doped $\mathrm{TiO}_{2}$ and the
$4.4 \%$ wt $\mathrm{Cr}$-doped $\mathrm{TiO}_{2}$. The quantitative phase analysis was calculated by comparing two methods: reference intensity ratio (RIR) and whole-pattern fitting (Rietveld analysis). The phase content of all samples calculated by RIR method are showed that the undoped $\mathrm{TiO}_{2}$ consist of anatase $(52.2 \%)$, rutile $(25.1 \%)$ and brookite $(22.7 \%)$ phases, while in the 1.1.\%wt Cr-doped $\mathrm{TiO}_{2}$ present anatase $(87.0 \%)$ and rutile $(13.0 \%)$. In the $3.9 \%$ wt $\mathrm{Cr}$-doped $\mathrm{TiO}_{2}$ are detected anatase $(91.0 \%)$, rutile $(2.8 \%), \mathrm{CrO}_{2}(2.7 \%)$, and $\mathrm{TiO}_{2}-\mathrm{II}(3.3 \%)$, while in the $4.4 \%$ wt $\mathrm{Cr}$-doped $\mathrm{TiO}_{2}$ have contents anatase $(96.0 \%)$, rutile $(2.2 \%), \mathrm{CrO}_{2}$ $(1.4 \%)$, and $\mathrm{TiO}_{2}-\mathrm{II}(0.4 \%)$. The Rietveld refinement method was applied to extract structural parameters of undoped $\mathrm{TiO}_{2}$ and a series of various \%wt Cr-doped $\mathrm{TiO}_{2}$ using the Fullprof program. The undoped $\mathrm{TiO}_{2}$ consist of anatase $(49.58 \%)$, rutile $(38.39 \%)$ and brookite $(12.03 \%)$, while in the $1.1 \%$ wt $\mathrm{Cr}$-doped $\mathrm{TiO}_{2}$ present anatase $(88.45 \%)$ and rutile $(11.50 \%)$ phases. In the $3.9 \%$ wt $\mathrm{Cr}$-doped $\mathrm{TiO}_{2}$ and in the $4.4 \% w t \mathrm{Cr}$ doped $\mathrm{TiO}_{2}$ respectively consist of $100 \%$ of anatase phase, while chromium dioxide and $\mathrm{TiO}_{2}-\mathrm{Il}$ phases can't be detected by Rietveld refinements. The undoped $\mathrm{TiO}_{2}$ was refined in the crystal system and space group of anatase (tetragonal, $14_{1} / \mathrm{amd}$ ), rutile (tetragonal, $\boldsymbol{P} 4_{2} / \mathrm{mnm}$ ) and brookite (orthorhombic, Poca), while the 1.1.\%wt $\mathrm{Cr}$-doped $\mathrm{TiO}_{2}$ was refined in the crystal system and space group of anatase (tetragonal, $\mathbf{I} 4_{1} / \mathrm{amd}$ ), rutile (tetragonal, $\boldsymbol{P} \mathbf{4}_{2} / \mathrm{mnm}$ ).

\section{ACKNOWLEDGEMENT}

This research was financially supported by a PUPT (Penelitian Unggulan Perguruan Tingi) Grant from Directorate General of Higher Education - Ministry of Education and Culture of the Republic of Indonesia No. 230/UPT-BOPTN/UN34.21/2014.

\section{REFERENCES}

[1] Yang, L., Hakki, A., Wang, F., and Macphee, D.E., 2018, Photocatalyst efficiencies in concrete technology: The effect of photocatalyst placement, Appl. Catal., B, 222, 200-208. 
[2] Chen, F., Zou, W., Qu, W., and Zhang, J., 2009, Photocatalytic performance of a visible light $\mathrm{TiO} 2$ photocatalyst prepared by a surface chemical modification process, Catal. Commun., 10 (11), 1510-1513.

[3] Munusamy, S., Aparna, R.S.L., and Prasad, R.G.S.V., 2013, Photocatalytic effect of $\mathrm{TiO}_{2}$ and the effect of dopants on degradation of brilliant green, Sustainable Chem. Processes, 4 (4), 1-4.

[4] Haghi, M., Hekmatafshar, M., Janipour, M.B., Gholizadeh, S.S., Faraz, M.K., Sayyadifar, F., and Ghaedi, M., 2012, Antibacterial effect of $\mathrm{TiO}_{2}$ nanoparticles on pathogenic strain of E. coli, IJABR, 3 (3), 621-624.

[5] Visai, L., De Nardo, L., Punta, C., Melone, L., Cigada, A., Imbriani, M., and Arciola, C.R., 2011, Titanium oxide antibacterial surfaces in biomedical devices, Int. J. Artif. Organs, 34 (9), 929-946.

[6] Günes, S., Marjanovic, N., Nedeljkovic, J.M., and Sariciftci, N.S., 2008, Photovoltaic characterization of hybrid solar cells using surface modified $\mathrm{TiO}_{2}$ nanoparticles and poly(3-hexyl)thiophene, Nanotechnology, 19 (42), 424009.

[7] Jasim, K., 2012, Natural dye-sensitized solar cell based on nanocrystalline $\mathrm{TiO}_{2}$, Sains Malaysiana, 41 (8), 1011-1016.

[8] Grätzel, M., 2005, Solar energy conversion by dyesensitized photovoltaic cells, Inorg. Chem., 44 (20), 6841-6851.

[9] Yan, P., Wang, X., Zheng, X., Li, R., Han, J., Shi, J., Li, A., Gan, Y., and Li, C., 2015, Photovoltaic device based on $\mathrm{TiO}_{2}$ rutile/anatase phase junctions fabricated in coaxial nanorod arrays, Nano Energy, $15,406-412$.

[10] Masuda, Y., and Kato, K., 2008, Liquid-phase patterning and microstructure of anatase $\mathrm{TiO}_{2}$ films on $\mathrm{SnO}_{2}: \mathrm{F}$ substrates using superhydrophilic surface, Chem. Mater., 20 (3), 1057-1063.

[11] Kim, H.M., Seo, S.B., Kim, D.Y, Bae, K., and Sohn, S.Y., 2013, Enhanced hydrophilic property of $\mathrm{TiO}_{2}$ thin film deposited on glass etched with $\mathrm{O}_{2}$ plasma, Trans. Electr. Electron. Mater., 14 (3), 152-155.

[12] Yang, L., Zhang, M., Shi, S., Lv, J., Song, X., He, G., and Sun, Z., 2014., Effect of annealing temperature on wettability of $\mathrm{TiO}_{2}$ nanotube array films, Nanoscale Res. Lett., 9 (1), 621.

[13] Hanaor, D.A.H., and Sorrell, C.C., 2011, Review of the anatase to rutile phase transformation, J. Mater. Sci., 46 (4), 855-874.

[14] Baur, W.H., 1961, Atomabstéinde und Bindungswinkel im Brookit, $\mathrm{TiO}_{2}$, Acta Cryst., 14, 214-216.

[15] Dette, C., Pérez-Osorio, M.A., Kley, C.S., Punke, P., Patrick, C.E., Jacobson, P., Giustino, F., Jung, S.J., and Kern, K., 2014, $\mathrm{TiO}_{2}$ anatase with a bandgap in the visible region, Nano Lett., 14 (11), 6533-6538.

[16] Pascual, J., Camassel, J., and Mathieu, H., 1978, Fine structure in the intrinsic absorption edge of $\mathrm{TiO}_{2}$, Phys. Rev. B: Condens. Matter, 18 (10), 5606-5614.

[17] Zallen, R. and Moret, M.P., 2006, The optical absorption edge of brookite $\mathrm{TiO}_{2}$, Solid State Commun., 137 (3), 154-157.

[18] Uyanga, E., Gibaud, A., Daniel, P., Sangaa, D., Sevjidsuren, G., Altantsog, P., Beuvier, T., Lee, C.H., and Balagurov, A.M., 2014, Structural and vibrational investigations of $\mathrm{Nb}$-doped $\mathrm{TiO}_{2}$ thin films, Mater. Res. Bull., 60, 222-231.

[19] Suwarnkar, M.B., Dhabbe, R.S., Kadam, A.N., and Garadkar, K.M., 2014, Enhanced photocatalytic activity of $\mathrm{Ag}$ doped $\mathrm{TiO}_{2}$ nanoparticles synthesized by a microwave assisted method, Ceram. Int., 40 (4), 5489-5496.

[20] Lei, X.F., .Xue, X.X., and Yang, H., 2014, Preparation and characterization of $\mathrm{Ag}$-doped $\mathrm{TiO}_{2}$ nanomaterials and their photocatalytic reduction of $\mathrm{Cr}(\mathrm{VI})$ under visible light, Appl. Surf. Sci., 321, 396-403.

[21] Avansi, W.Jr., Arenal, R., de Mendonça, V.R., Ribeiro, C., and Longo, E., 2014, Vanadium-doped $\mathrm{TiO}_{2}$ anatase nanostructures: the role of $\mathrm{V}$ in solid solution formation and its effect on the optical properties, CrystEngComm, 16 (23), 5021-5027.

[22] Moradi, H., Eshaghi, A., Hosseini, S.R., and Ghani, K., 2016, Fabrication of Fe-doped $\mathrm{TiO}_{2}$ nanoparticles and investigation of photocatalytic decolorization of reactive red 198 under visible light irradiation, Ultrason. Sonochem., 32, 314319.

[23] Zhao, Y., Li, C., Liu, X., Gu, F., Du, H.L., and Shi, L., 2008, Zn-doped $\mathrm{TiO}_{2}$ nanoparticles with high photocatalytic activity synthesized by hydrogenoxygen diffusion flame, Appl. Catal., B, 79 (3), 208-215.

[24] Peng, Y.H., Huang, G.F., and Huang, W.Q., 2012, Visible-light absorption and photocatalytic activity of $\mathrm{Cr}$-doped $\mathrm{TiO}_{2}$ nanocrystal films, Adv. Powder Technol., 23 (1), 8-12.

[25] Dubey, R.S., and Singh, S., 2017, Investigation of structural and optical properties of pure and chromium doped $\mathrm{TiO}_{2}$ nanoparticles prepared by solvothermal method, Results Phys., 7, 12831288.

[26] Ould-Chikh, S., Proux, O., Afanasiev, P., Khrouz, L., Hedhili, M.N., Anjum, D.H., Harb, M., Geantet, C., Basset, J.M., and Puzenat, E., 2014, Photocatalysis with chromium-doped $\mathrm{TiO}_{2}$ : Bulk and surface doping, ChemSusChem, 7 (5), 13611371. 
[27] Klug, H.P., and Alexander, L.E., 1954, X-Ray Diffraction Procedures: For Polycrystalline and Amorphous Materials, John Wiley \& Sons., New York, 992.

[28] Snyder, R.L. and Bish, D.L., 1989, "Quantitative Analysis" in Modern Powder Diffraction, Bish, D.L., and Post, J.E., Eds., Mineralogical Society of America, Washington, D.C., 20, 101-144.

[29] Bish, D.L, and Howard, S.A., 1988, Quantitative phase analysis using the Rietveld method, J. Appl. Crystallogr., 21, 86-91.

[30] Pecharsky, V., and Zavalij, P., 2009, Fundamentals of Powder Diffraction and Structural Characterization of Materials, $2^{\text {nd }}$ Ed., SpringerVerlag US, 744.
[31] Rich, R., 2007, Inorganic Reactions in Water, $1^{\text {st }}$ Ed., Springer-Verlag Berlin Heidelberg, 521.

[32] Rietveld, H.M., 1969, A profile refinement method for nuclear and magnetic structures, J. Appl. Cryst., 2, 65-71.

[33] Roisnel, T., and Ridriguez-Carvajal, J., 2009, Winplotr a graphic tool for powder diffraction, CNRS-Lab. de Chimie du Solide et Inorganique Moléculaire Université de Rennes.

[34] Rodríguez-Carvajal, J., 2009, An Introduction to the Program Fullprof, Laboratoire Léon Brillouin (CEA-CNRS) CEA/Saclay, Gif sur Yvette, France.

[35] Shannon, R.D., 1976, Revised effective ionic-radii and systematic studies of interatomic distances in halides and chalcogenides, Acta Cryst., A32, 751767. 